\title{
PELATIHAN MENGGUNAKAN SISTEM INFORMASI GEOGRAFIS LOKASI LEMBAGA SWADAYA MASYARAKAT DI KESBANGPOL PEKANBARU
}

\author{
Roki Hardianto'), Fajrizal $^{2)}$, dan Yuvi Darmayunata ${ }^{3)}$ \\ 1,2,3)Teknik Informatika, Fakultas Ilmu Komputer, Universitas Lancang Kuning \\ E-mail: roki@unilak.ac.id, fajrizal@unilak.ac.id, yuvidarmayunata@unilak.ac.id
}

\begin{abstract}
ABSTRAK
Pengabdian kepada masyarakat dilakukan di Kantor Kesatuan Bangsa dan Politik (Kesbangpol) Kota Pekanbaru, berupa pelatihan terhadap operator Kesbangpol Pekanbaru terhadap pengelolaan Sistem Informasi Geografis (GIS) terhadap pemetaan Lembaga Swadaya Masyarakat (LSM) yang terdaftar dan teregister. Pengabdian ini merupakan tindak lanjut terhadap penelitian pembuatan Sistem Informasi Geografis (GIS) terhadap pemetaan Lembaga Swadaya Masyarakat (LSM). Diharapkan dengan menggunakan system ini, proses record data LSM yang terdaftar di Kesbangpol lebih terintegrasi dan mudah diakses oleh public sebagaimana amanat dari pada UU. Pengabdian ini merupakan bentuk kerjasama nyata antara Fakultas Ilmu Komputer Universitas Lancang Kuning dengan lembaga pemerintah dalam hal ini Kantor Kesbangpol Pekanbaru.
\end{abstract}

Kata kunci : Kesbangpol, GIS, LSM, Pekanbaru, Komputer

\section{ABSTRACT}

Community Service is carried out at the Office of National Unity and Politic (Kesbangpol) of Pekanbaru City, in the form of training of Pekanbaru Kesbangpol operators in managing Geographical Information System (GIS) on the mapping of registered and registered LSM. This dedication is a follow up to the research on the making of a Geographic Information System (GIS) on the mapping of LSM. It is hoped that by using this system, the data recording process of LSM registered at Kesbangpol will be more integrated and easily accessible to the public as mandated by the Law. This dedication is a form of real collaboration between the Faculty of Computer Science, University of Lancang Kuning with government agencies in this case the Kesbangpol Pekanbaru Office.

Key words: Kesbangpol, GIS, LSM, Pekanbaru, Computer 


\section{PENDAHULUAN}

Badan Kesatuan Bangsa dan Politik Kota Pekanbaru beralamatkan di jalan Arifin Ahmad No.39. Badan yang bertugas sebagai menyusun dan sebagai pelaksana kebijakan suatu daerah pada urusan bidang ideologi dan kewaspadaan, wawasan politik, kebangsaaan, ketahanan seni, budaya, ekonomi dan budaya. Selain itu Kesbangpol juga mempunyai peranan dalam pengendalian dan pengawasan Lembaga Swadaya Masyarakat (LSM) dan masih banyak tugas penting Kesbangpol. Dalam peranannya pada saat ini Kesbangpol Pekanbaru belum mempunyai suatu system yang bisa mempermudah kerja dalam pengelolaan.

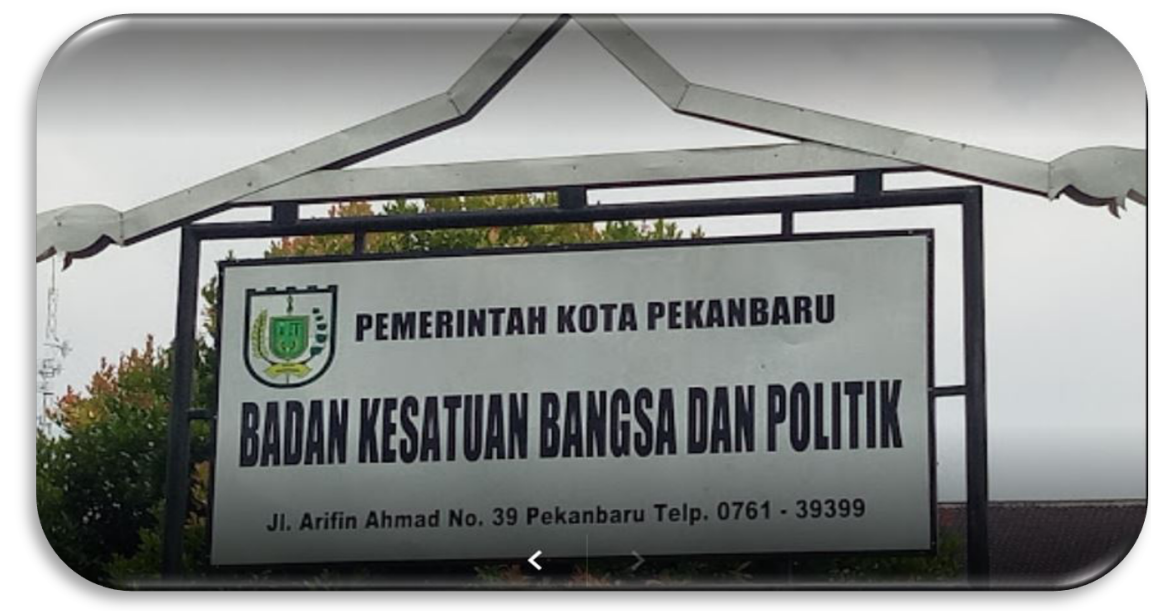

Gambar 1. Plang nama Kesbangpol Pekanbaru

Dalam menjalankan fungsi dan tugas pengawasannya, Kesbangpol Pekanbaru masih menggunkan system pencatatan manual. Begitu juga dalam tugas pemetaan lokasi LSM yang terdaftar di Kesbangpol.

Maka dari pada itu Fakultas Ilmu Komputer melakukan IbM Pelatihan Menggunakan Sistem Informasi Geografis Lokasi Lembaga Swadaya Masyarakat Di Kesbangpol Pekanbaru, Riau. Pelatihan ini adalah lanjutan dari hasil penelitian yang dilakukan di Kesbangpol Pekanbaru.

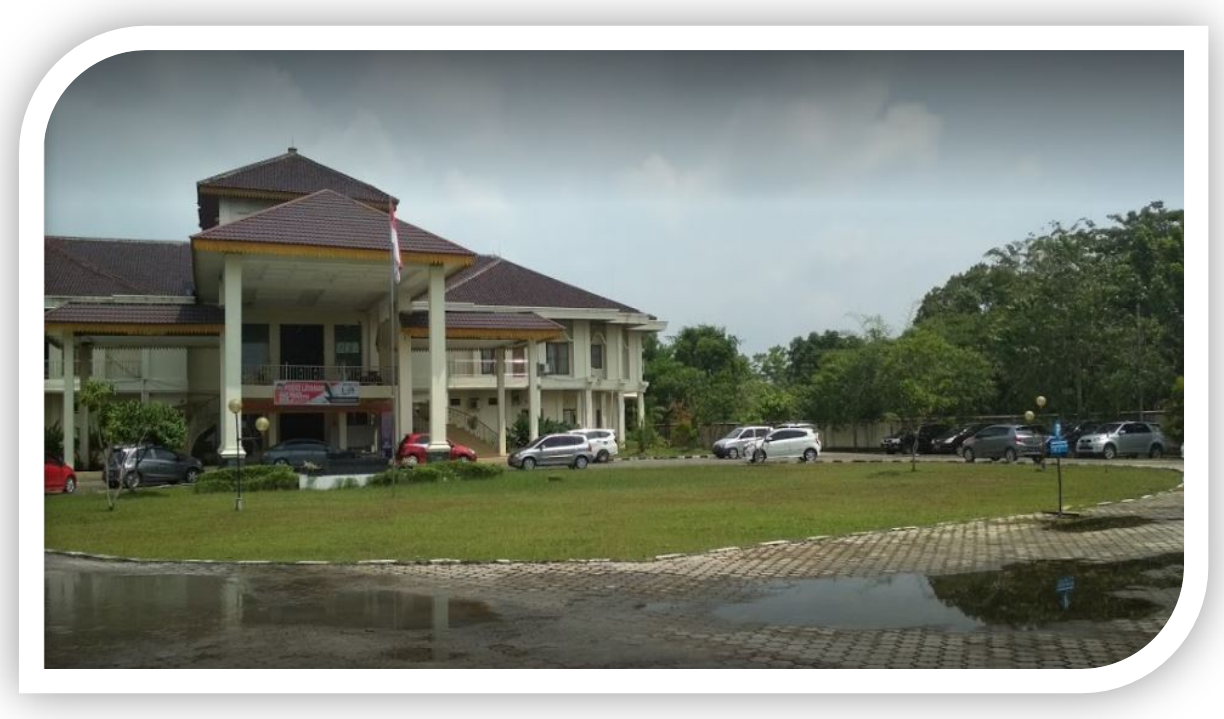

Gambar 2. Lokasi kantor Kesbangpol 
Sistem ini dibangun agar Kesbangpol Pekanbaru dapat dipermudah dalam menjalankan tugas dan fungsinya pengawasan dan pengelolaan. Dengan adanya GIS pemetaan ini diharapkan bisa menawarkan solusi baru terhadap pelayanan di Kesbangpol Pekanbaru. Publik dalam pengaksesan data jauh lebih mudah baik informasi seputar LSM dan Organisasi Masyarakat yang terdaftar hingga alamat dari pada LSM dan Organisasi Masyarakat dalam bentuk peta Google Map.

\section{TINJAUAN PUSTAKA}

Menurut (Pratama, Jackson, \& Patra, 2012) menjelaskan bahwa Lembaga Swadaya Masyarakat (LSM) sering disebut organisasi non pemerintah keberadaanya sangat mewarnai kehidupan politik di Indonesia. Perkembangan politik, demokrasi, pembangunan ekonomi dan kemajuan teknologi informasi merupakan faktor-faktor yang mendorong terus bertambahnya jumlah LSM di Indonesia. Karena dengan LSM masyarakat bisa mengekspresikan aspirasi yang masyarakat berikan.

Pasal 7 Peraturan Menteri Dalam Negeri Nomor 44 tahun 2009 Tentang Pedoman Kerja Sama Departemen Dalam Negeri dan Pemerintah Daerah dengan Organisasi Kemasyarakatan dan Lembaga Nirlaba Lainnya Dalam Bidang Kesatuan Bangsa dan Politik Dalam Negeri, menyatakan bahwa Kesbangpol melakukan kerja sama pemerintah daerah kabupaten/kota dengan organisasi kemasyarakatan dan/atau lembaga nirlaba lainya yang mempunyai ruang lingkup kabupaten/kota.

Dalam menjalankan fungsi dan tugas pengawasannya, Kesbangpol Pekanbaru masih menggunkan system pencatatan manual. Begitu juga dalam tugas pemetaan lokasi LSM yang terdaftar di Kesbangpol. Banyaknya LSM yang mendaftar di kota Pekanbaru menjadi kesulitan dalam pemetaan lokasi LSM. Maka sangat diperlukan system dalam mengelola ini semua. Menurut (Apriyanti \& Firman, 2014) dalam jurnalnya menjelaskan dalam menyusun dan membangun GIS diperlukan perencanaan yang matang seperti flowchart dan tahapan nya.

\section{METODE PELAKSANAAN}

Pengabdian Kepada Masyarakat ini dilaksanakan di Labor Komputer Fakultas Ilmu Komputer Universitas Lancang Kuning dengan metode seminar, tanya jawab, praktek. Pelatihan dilakukan selama satu hari dimana peserta akan mendapatkan modul ajar untuk pelatihan.

Metode seminar dan tatap muka diberikan saat pemberian materi dengan menggunakan slide persentasi dan handout materi. Pada awal pertemuan para ASn/admin akan diberikan praktek langsung tentang tingkat pemahaman kepada Sistem Infromasi Geografis. Admin Kesbangpol akan mencobakan langsung penggunaan dan melakukan kelola system yang telah berjalan. Metode evaluasi pencapaian target dilakukan pada awal dan akhir kegiatan. Hal ini untuk mengetahui tingkat pengetahuan peserta dan menerima masukan untuk perbaikan pada kegiatan kegiatan berikutnya. Secara rinci kegiatan pengabdian yang akan dilakukan sebagai berikut :

1. Kegiatan perkenalan

2. Pengenalan Sistem Informasi Geografis

3. Pendalaman materi pelatihan

4. Melakukan tanya jawab

5. Praktek langsung 
Kegiatan ini menggunakan bebarapa perangkat pendukung di antaranya adalah :

1. Perangkat komputer / laptop

2. Sistem Informasi Geografis LSM melalui laman website

3. Infocus

4. Smartphone

\section{HASIL DAN PEMBAHASAN}

Kegiatan Pengabdian Kepada Masyarakat dilaksanakan di Labor Komputer Fakultas Ilmu Komputer Universitas Lancang Kuning pada 29 Maret 2019. Hadir 6 operator perwakilan dari Kantor Kesbangpol dalam pelatihan ini. Pengabdian ini merupakan tindak lanjut kerjasama antara Fakultas Ilmu Komputer Universitas Lancang Kuning dengan Kantor Kesbangpol Pekanbaru terhadap penyedian system informasi geografis pemetaan terhadap lokasi LSM dan Organisasi Masyarakat yang terdaftar di Kesbangpol Pekanbaru. Kerjasama ini merupakan wujud pelaksanaan Tridarma Perguruan Tinggi Fakultas Ilmu Komputer Universitas Lancang Kuning.

Pada kegiatan Pengabdian ini sebagai pematerinya adalah anggota team Pengabdian, Roki Hardianto, M.Kom dengan mahasiswa Fasilkom Van Resky Nababan, S.Kom. Kegiatan ini dibuka oleh dekan Fakultas Ilmu Komputer Universitas Lancang Kuning, H.Fajrizal, S.P, M.Kom yang juga selaku ketua team Pengabdian Kepada Masyarakat.

Metode kegiatan pengabdian ini adalah pemateri memperkenalkan team pengabdian dan seputar Fakultas Ilmu Komputer Universitas Lancang Kuning kemudian dilanjutkan menjelaskan tujuan dan fungsi system dibangun. Kemudian dijelaskan roadmap yang berjalan dalam system dalam pengelolaan oleh admin. Peserta kemudian diberikan penjelasan dan praktek langsung kepada system yang telah di hosting secara umum oleh team pengabdian. Kemudian operator kesbangpol melakukan login dan bisa langsung mengelola system. Seperti cara input LSM dan organisasi masyarakat yang akan diinputkan dan penjelasan bagaimana pengelolaan berita dan hal lain didalam system.

Luaran yang hendak dicapai pada pengabdian ini adalah bagaimana operator Kesbangpol Pekanbaru dapat melakukan pengelolaan system yang telah dibangun. Selain operator, admin juga bisa membantu dalam mengelola system apabila operator mengalami kendala. Karena level admin dibagi menjadi 2 yaitu operator dan admin.

Operator hanya bisa menambah, merubah dan menghapus data LSM, Ormas, Yayasan dan Perkumpulan yang terdaftar serta menambah berita. Sedangkan admin selain tugas operator juga bisa menambah dan menghapus operator system.

Selain itu tujuan lain yang hendak dicapai adalah terbitnya jurnal hasil pengabdian yang terbit secara nasional dan juga buku manual dalam pengelolaan system yang bisa membantu operator dan admin dalam proses pengelolaan system. Team pengabdian juga menerbitkan berita pada media daring / cetak. Serta menggunakan alat peraga berupa spanduk dan standing banner.

Dibawah ini adalah halaman system informasi yang telah dibagun oleh team penelitian dan pengabdian Fakultas Ilmu Komputer Universitas Lancang Kuning. Halaman beranda adalah laman awal dari web system informasi geografis kesbangpol pekanbaru. Pada laman ini menampilkan data yang tersaji dalam system ini, seperti pada gambar di bawah ini. 


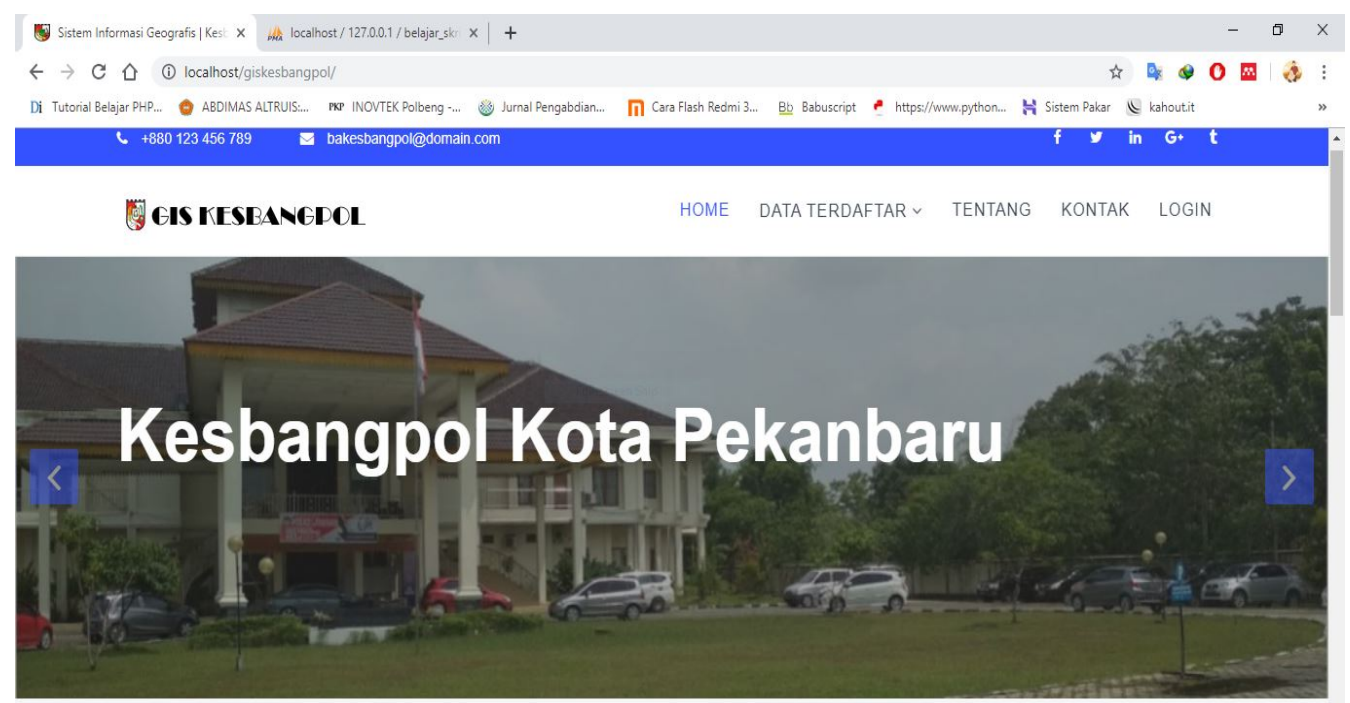

* 0 口

Gambar 3. Halaman beranda GIS Kesbangpol

Pada laman data LSM akan menampilkan data LSM dan Organisasi Masyarakat yang telah mendaftar di Kesbangpol Pekanbaru secara akurat dan detail.

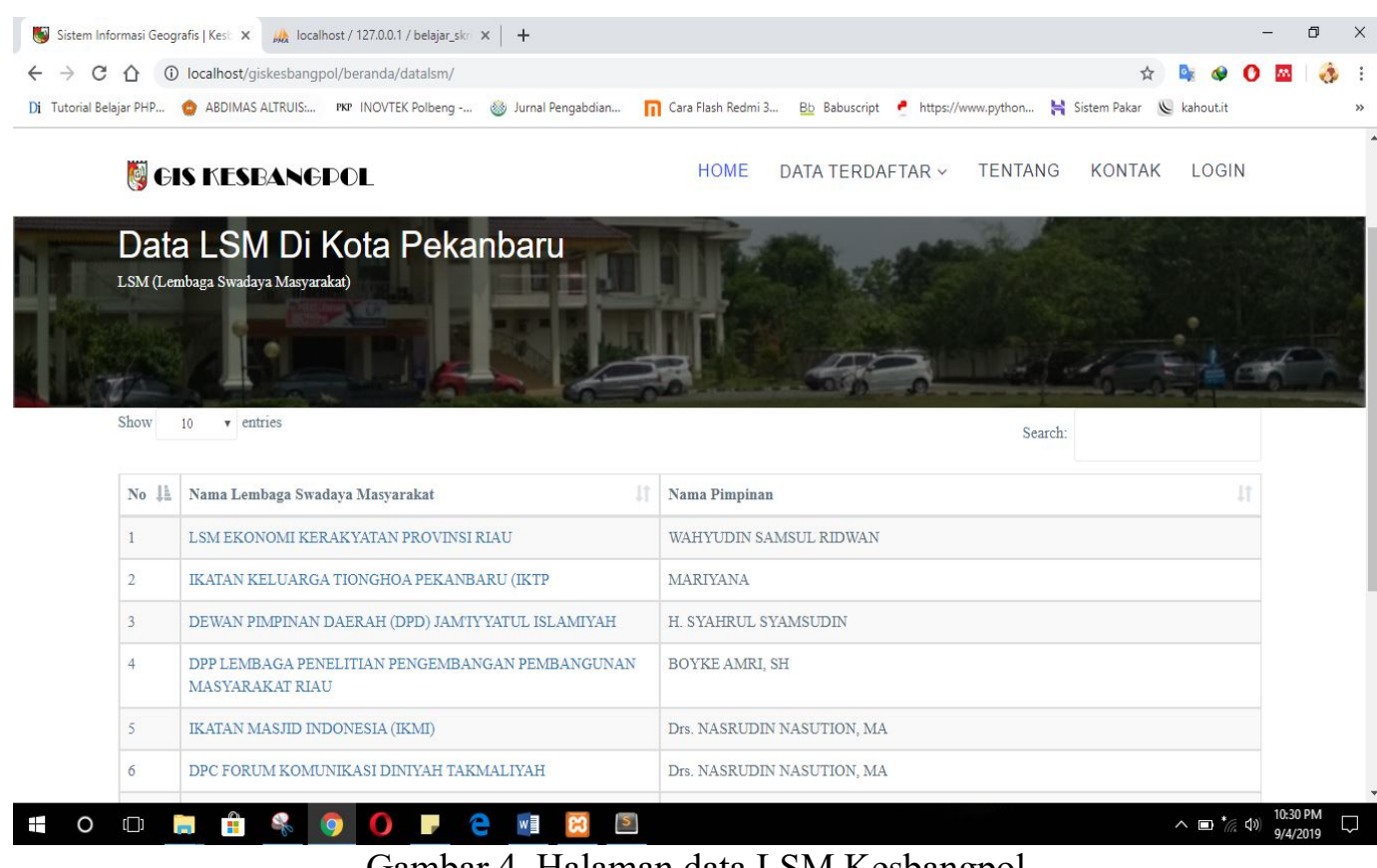

Gambar 4. Halaman data LSM Kesbangpol 
Pada laman ini menampilkan visi dan misi dari kantor Kesbangpol Pekanbaru hingga sejarah dan struktur organisasi.

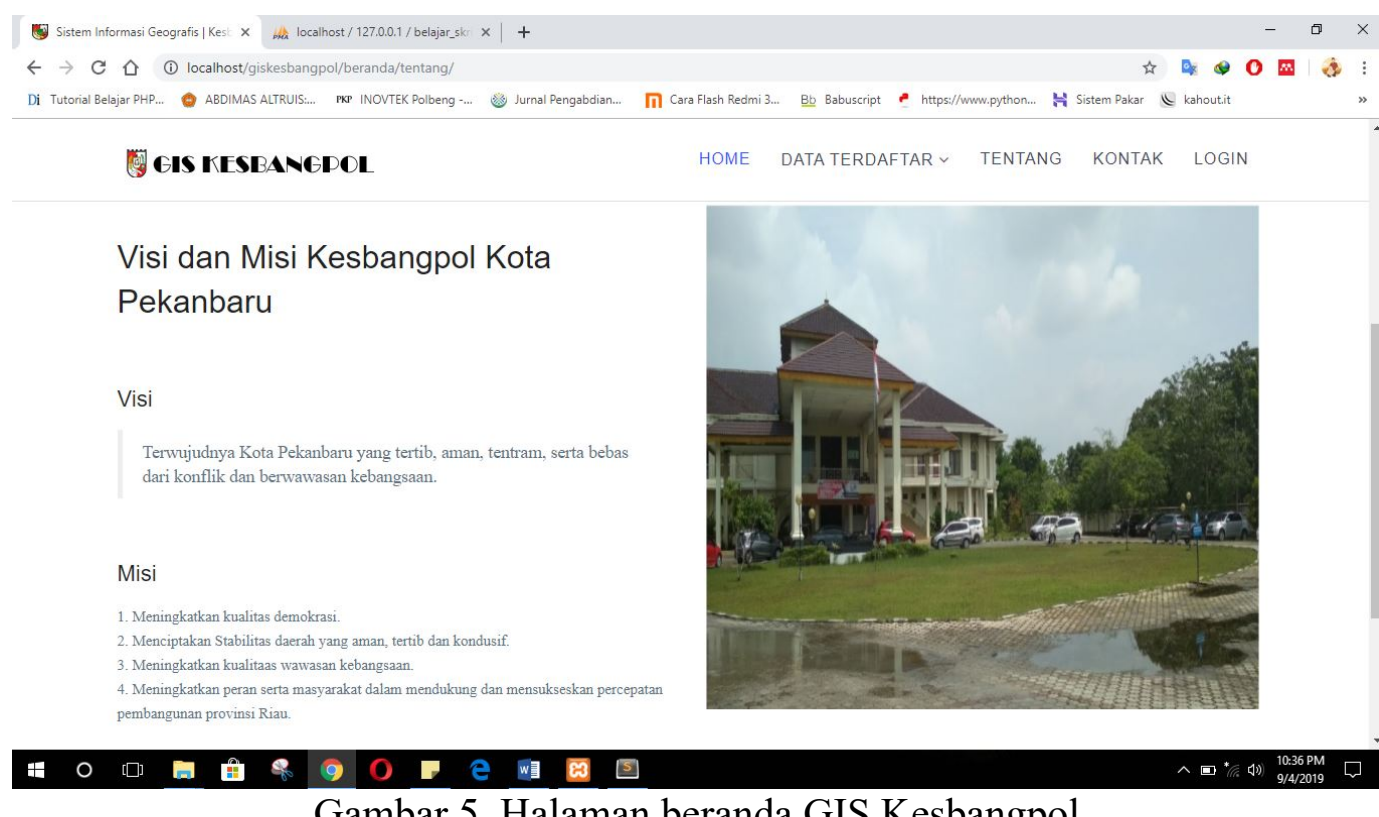

Gambar 5. Halaman beranda GIS Kesbangpol

Pada laman admin ini adalah halaman kelola system informasi geografis secara keselurahan termasuk halaman kelola yang dilakukan operator system.

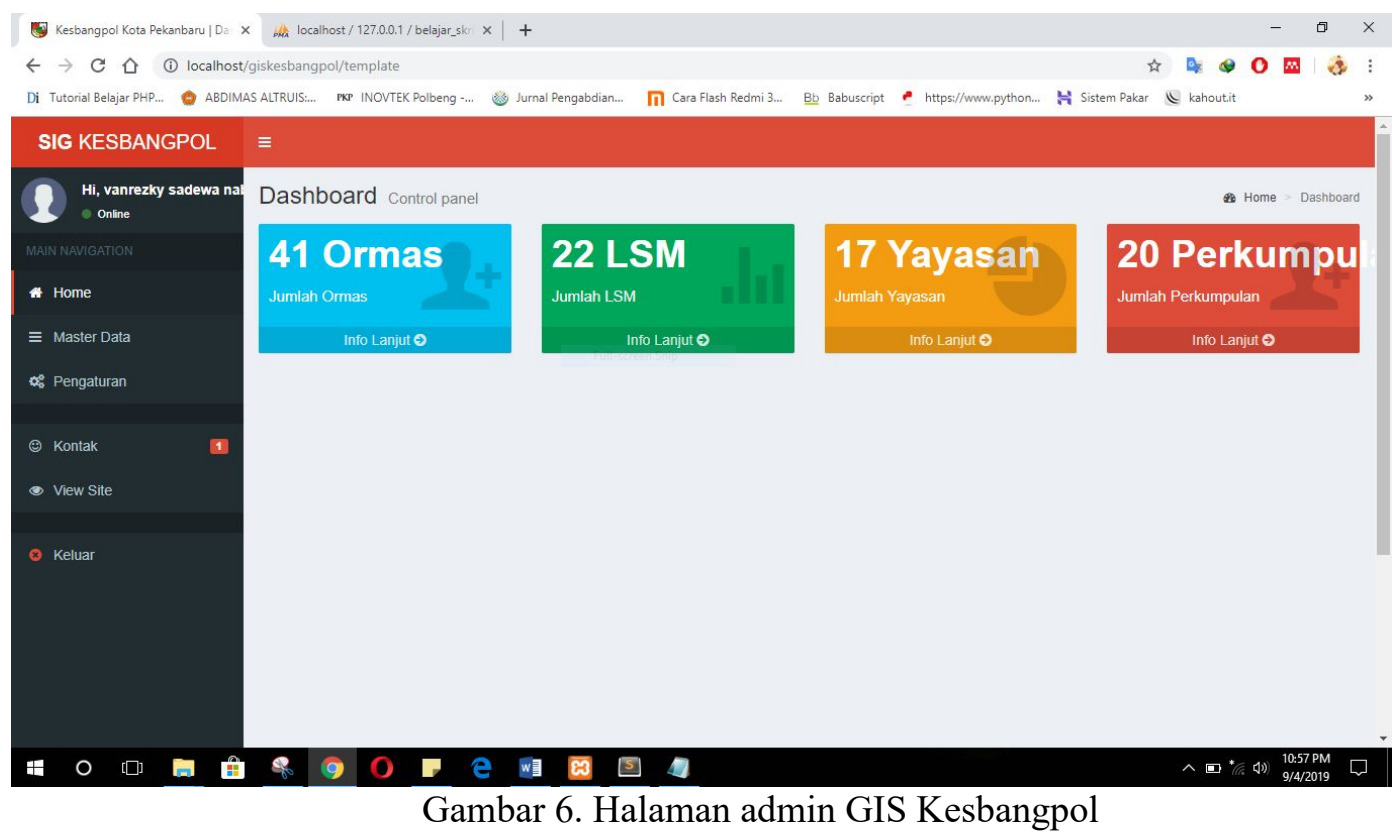

Berikut ini adalah foto-foto kegiatan pengabdian yang telah dilaksanakan antara Fakultas Ilmu Komputer Universitas Lancang Kuning dengan Kesbangpol Pekanbaru : 


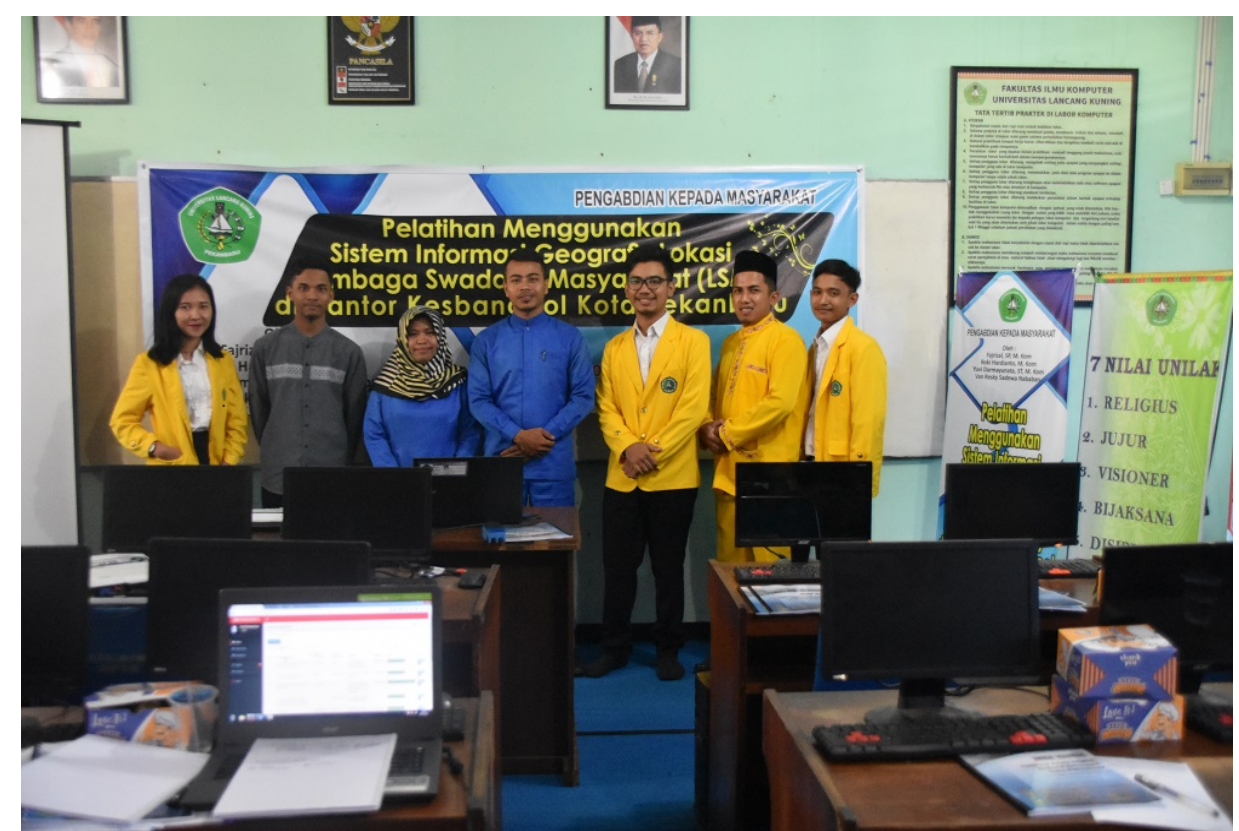

Gambar 7. Tim pelaksana pengabdian

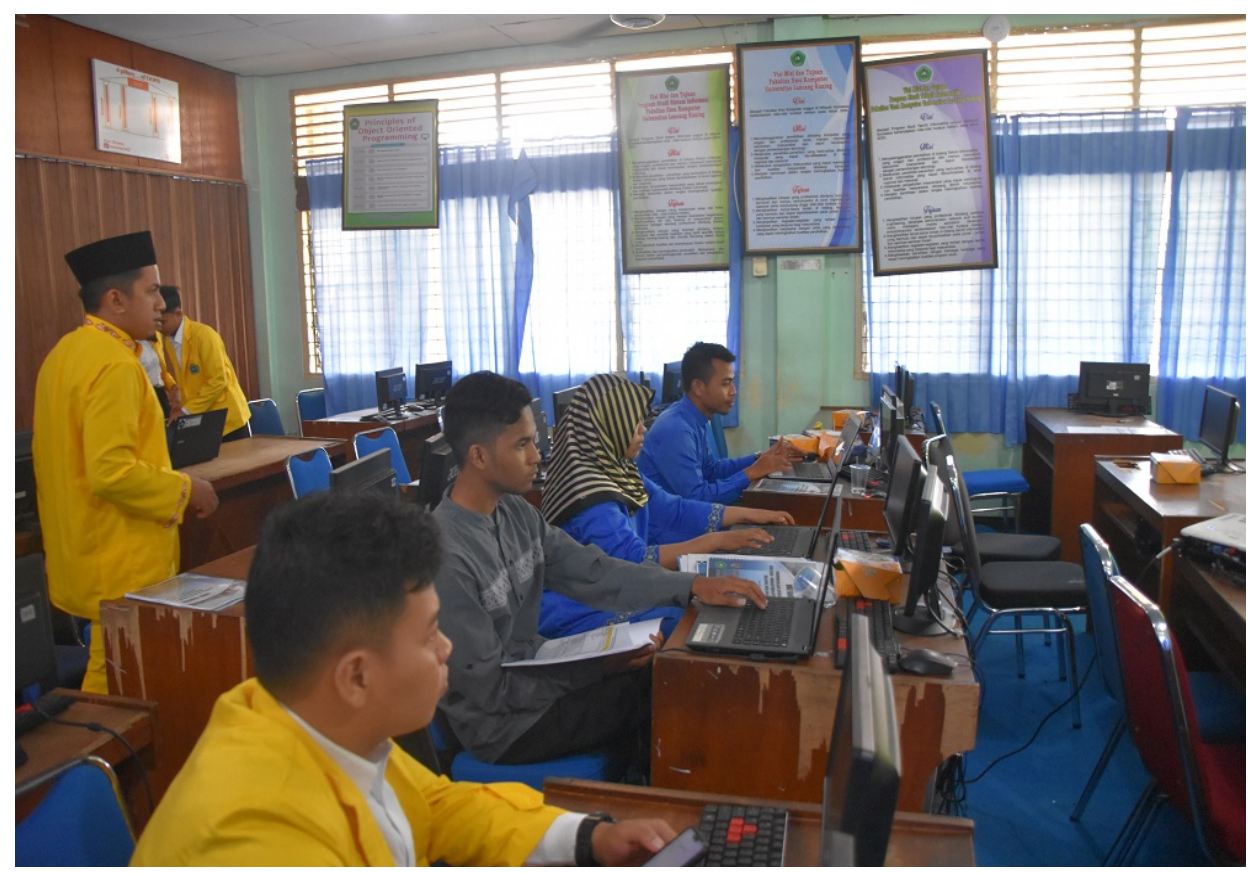

Gambar 8. Kegiatan pelatihan

\section{KESIMPULAN}

Dari kegiatan pengabdian kepada masyarakat ini diharapkan bisa membantu Kesbangpol Pekanbaru dalam pelayanan publik melalui system yang dibangun. Dari hasil pengabdian yang dilakukan, operator yang dilatih dalam pengelolaan system informasi sudah menguasai sepenuhnya. Hal ini dibuktikan dengan praktek yang dilaksanakan pada saat kegiatan pengabdian serta banyaknya pertanyaan yang diajukan pada saat pemateri memaparkan materi.

Terimakasih kepada Fakultas Ilmu Komputer Universitas Lancang Kuning telah mempermudahkan team dalam pelaksanakan pengabdian begitu juga kepada Kesbangpol 
Pekanbaru yang telah memudahkan dalam penyelesaian pengabdian hingga pelaporan dan juga kepada team pengabdian yang telah berkerja.

\section{DAFTAR PUSTAKA}

[1]. Apriyanti, R., \& Firman, R. 2014. Pemanfaatan Sistem Informasi Geografis (Sig) Dalam Penentuan Lokasi Perumahan Di Kota Depok, 8(Kommit).

[2].Erna, K., \& Eko, A. 2013. Sistem Informasi Geografis Pemetaan Potensi Sma / Smk Berbasis Web ( Studi Kasus : Kabupaten Kebumen ). Jurnal Sarjana Teknik Informatika, 1 , 41-49. Https://Doi.Org/Http://Dx.Doi.Org/10.12928/Jstie.V2i1.2600

[3]. Nugroho, B. 2011. Sistem Informasi Berbasis Web Dengan PHP Dan Mysql, 11(1), 51-60.

[4].Pratama, S. S., Jackson, C., \& Patra, E. E. 2012. Pelaksanaan Pembinaan Lembaga Swadaya Masyarakat Oleh Badan Kesatuan Bangsa, Politik Dan Perlindungan Masyarakat Kabupaten Lampung Timur, 1-10.

[5].Trise, P. D. W., \& Kadris. 2016. Sistem Informasi Geografis Pemetaan Sarana Prasarana Departeman Agama Kota Sungai Penuh Berbasis Web. Jurnal TEKNOIF, 4(2), 76-81. 